\title{
Gérard de Nerval, Les Confidences de Nicolas. Histoire d'une vie littéraire au XVIII siècle
}

\section{Lise Sabourin}

\section{(2) OpenEdition}

\section{Journals}

\section{Édition électronique}

URL : http://journals.openedition.org/studifrancesi/8316

DOI : 10.4000/studifrancesi.8316

ISSN : 2427-5856

\section{Éditeur}

Rosenberg \& Sellier

\section{Édition imprimée}

Date de publication : 1 mai 2009

Pagination : 197

ISSN : 0039-2944

\section{Référence électronique}

Lise Sabourin, "Gérard de Nerval, Les Confidences de Nicolas. Histoire d'une vie littéraire au xvII" siècle », Studi Francesi [En ligne], 157 (LIII | I) | 2009, mis en ligne le 30 novembre 2015, consulté le 10 janvier 2021. URL : http://journals.openedition.org/studifrancesi/8316 ; DOI : https://doi.org/10.4000/ studifrancesi.8316

Ce document a été généré automatiquement le 10 janvier 2021.

\section{(c) (i) () $\Theta$}

Studi Francesi è distribuita con Licenza Creative Commons Attribuzione - Non commerciale - Non opere derivate 4.0 Internazionale. 


\title{
Gérard de Nerval, Les Confidences de Nicolas. Histoire d'une vie littéraire au XVIII siècle
}

\author{
Lise Sabourin
}

\section{RÉFÉRENCE}

GÉRARD DE NERVAL, Les Confidences de Nicolas. Histoire d'une vie littéraire au XVIII siècle, édition établie, annotée et présentée par Michel BRIX, Éditions du Sandre, Paris, diffusion L'Harmattan, 2008, pp. 209.

1 Parues en feuilleton durant l'été 1850, puis reprises en volume dans Les Illuminés en 1852, ces Confidences de Nicolas constituent une recomposition d'un portrait de Rétif de La Bretonne par Nerval à la lumière de textes autobiographiques laissés par son modèle, qui se voulait «sans détours et sans voiles» (notamment M. Nicolas ou le cœur humain dévoilé dont il s'inspire librement). Michel Brix nous en offre la relecture par une édition annotée avec soin et préfacée avec finesse (pp. 5-43).

2 Remis en évidence par les articles de Monselet, Montépin et Leroux en 1849, cet utopiste du $\mathrm{XVIII}^{\mathrm{e}}$ siècle, annonciateur de Fourier, se trouve reflété par un biographe non dénué de similitudes avec l'écrivain portraituré. Au point que cette étude peut apparaître comme un avant-texte de Sylvie (1853), même si les inconséquences du comportement nervalien dues à la superposition d'une unique figure sur plusieurs femmes n'atteignent pas le libertinage rétivien, transcrit dans Le Paysan perverti.

L'esquive des détails licencieux ne vise pas à défendre la réputation de Rétif, fort critiqué en ce milieu de XIx ${ }^{\mathrm{e}}$ siècle, car Nerval ne se prive pas de blâmer l'homme, ni d'ailleurs l'œuvre, selon lui minée par la dépravation de la vie. Mais le rêve arcadien sur Nicolas (dont le père, Edme Rétif, laboureur modeste et vertueux, a également fourni l'objet d'un livre à Gérard) lui semble avoir été brisé par une excessive méfiance du christianisme du XVIII ${ }^{e}$ siècle envers toute euphorie sensuelle, même dans le mariage: le 
jeune Nicolas n'aurait donc trouvé que l'hypocrisie morale pour masquer ses pulsions, même aux épicuriens matérialistes des Lumières, plus prudes qu'il n'y parait. Devenu un «libertin résolu», Rétif s'enfonce dans la déchéance, multipliant les aventures nées de ses obsessions sexuelles qui le mettent souvent en situation grotesque, sourd à tout rappel aux limites. Ce séducteur - corrupteur mais aussi réformateur pré-communiste est aussi un écrivain, réaliste aux yeux du $\mathrm{xIX}^{\mathrm{e}}$, dont Nerval considère le goût littéraire comme entravé par l'immoralité, en métonymie du chaos de la société prérévolutionnaire.

4 Cet essai «qui tient du réquisitoire» (p.32) au lieu de réhabiliter ce «double» en fait si proche accomplit peut-être pourtant le projet de Rétif lui-même: jugé mentalement malade, sans en avoir autant conscience que Nerval, il sert aussi de prétexte à des masques narratifs qui révèlent la hantise de la faute, spécifique également du futur auteur d'Aurélia. 